\title{
Ứstünlük kuramı bağlamında Türk ve İngiliz siyasetinde mizahın kullanımı üzerine bir karşılaştırma
}

\section{Erkan KALAYCI 1}

\begin{abstract}
APA: Kalaycı, E. (2019). Üstünlük kuramı bağlamında Türk ve İngiliz siyasetinde mizahın kullanımı üzerine bir karşılaştırma. RumeliDE Dil ve Edebiyat Araștırmaları Dergisi, (15), 195-207. DOI: $10.29000 /$ rumelide. 580498
\end{abstract}

$\ddot{\mathbf{O} z}$

Gülmek, insanların gündelik hayatları içerisinde sıklıkla gerçekleştirdikleri eylemlerden biridir ve bu eylem mizahın en önemli sonuçlarından biridir. Gazetelerde yayınlanan köşe yazılarında, televizyon ve radyo programlarında, şehrin muhtelif yerlerinde karşımıza çıkan ilan panolarında, bir pazarda satılan ürünün niteliğini anlatmak için atılan sloganlarda, motorlu taşıtların genellikle tamponlarına veya arka camlarına yapıştırılan çıkartmalarda ve bunlara benzer şekilde gündelik hayatımızın her anında mizahın karşımıza çıkması söz konusu olabilmektedir. En önemli amacı ve sonucu gülmek ve güldürmek olan mizah bir duyguyu, bir düşünceyi, bir mesajı iletmek noktasında etkili bir iletişim aracı olduğu kadar mahir ellerde etkili bir silaha da dönüşebilmektedir. Bu bağlamda tarafların muarızlarını çaresiz bırakma noktasında etkili bir üstünlük kurma aracı olarak siyasette ve kimi zaman savaşlarda bile mizahın bu gücünden yararlanıldı̆̆ı örnekler mevcuttur. Bu çalışmada, İngiliz ve Türk siyasetinde verilen mizah örnekleri üzerinden bir karşılaştırma yapılacaktır. Dönem olarak, bir karşılaştırma yapabilmek adına yeteri kadar kayıt alınmış örneğe rastlamamız dolayısıyla 19.yüzyıl ve sonrasında ağırlıklı olarak yüz yüze iletişim ortamında verilmiş örnekler tercih edilmiştir. Öncelikle Türk ve İngiliz toplumlarında mizahın, belirttiğimiz yüzyllar içerisindeki durumu ve otoritenin mizaha bakışında öne çıkan noktalar genel hatlarıyla değerlendirilecektir. Ardından da siyasal alanda verilen örnekler ele alınacaktır. Bu örnekler üstünlük kuramı açısından irdelenecektir. Örneklerde yer alan verilerden hareketle, her iki toplumun siyasal hayatında mizahın kullanımı üzerinden bir karşılaştırma ile çalışma sona erecektir.

Anahtar kelimeler: Mizah, siyaset, üstünlük kuramı.

\section{A comparison on the utilisation of humor in Turkish and English politics in context of superiority tehory}

\begin{abstract}
Laughing as an activity takes place vey oftenly in the daily life of people and this activity is the one of the most important consequence of humor. In the columns of newspapers, television and radio shows, on the billboards spread across the various locations of a city, sometimes in the slogans performed by the countermen of the bazaars, on the bumpers or rear windows of the motor vehicles and etc. we may run into humorous objects everywhere in our daily lives. Humour, one of the important consequence and purpose of which is to laugh and to make somebody laugh, would be an effective tool for conveying a message, an idea or expressing a feeling. Humor would also turn into an effective weapon in the hands of a gifted person. In this sense, with the intent of leaving the rivals weak at the knees and claiming superiority over them, it would also be utilised in the politics and
\end{abstract}

$1 \quad$ Ars. Gör. Dr., Kırklareli Üniversitesi, Fen-Edebiyat Fakültesi, Türk Dili ve Edebiyatı Bölümü, Halk Bilimi ABD (Kırklareli/ Türkiye), kalaycierkan@klu.edu.tr, ORCID ID: 0000-0002-9734-7435 [Makale kayıt tarihi: 22.04.2019-kabul tarihi:17.06.2019; DOI: 10.29000/rumelide.580498] 


\begin{abstract}
sometimes even in the wars. In this paper, a comparison will be made depending on the humorous instances of English and Turkish politics. Because of encountering sufficient examples gathered and written out from face to face communication medium which give us a chance to make a comparison, 19th Century and the following years are choosen. Firstly, we will take a brief look at the general status of humor in Turkish and English societies and the prominent points of how the authority interprets humor throughout the period given above. Then, the examples which were produced in the political sphere will be discussed with regard to superiority theory. With reference to the examples, this paper will be concluded with a comparison depending on the way of the utilisation of humor in the political spheres of Turkish and English societies.
\end{abstract}

Keywords: Humor, politics, superiority theory.

\title{
Giriş
}

Mizah, insanların gündelik hayatlarının akışı içerisinde televizyonda veya ilan panolarındaki reklamlarda, semt pazarlarında tezgahtarların müşterilerinin dikkatini çekmek için kullandığı sloganlarda, filmlerde, tiyatroda, sadece gülme ve eğlenme odaklı stand-up gösterilerinde, iş hayatında oldukça tumturaklı olması beklenen bir konuşma metninin içine serpiştirilmiş vaziyette, seçim zamanı geldiğinde siyasal partilerin propaganda çalışmalarında sıklıkla karşılaştığımız bir kavramdır. Mizahın malzemesine bağlı olarak fiziksel manadaki çıktısı olan gülme eylemi, genel olarak mizahın gündelik hayatın tekdüzeliğinden sıyrılmaya, gerginliklerden arınmaya ve hoşça vakit geçirmeye yarayan bir araç olarak düşünülmesine yol açmaktadır. Mizahın bu noktada işlevsel olarak olumlu çıtılara sahip olması onun pozitif bir tabiata sahip olduğunu düşündürmekle birlikte negatif (ironi, istihza ve alaycılık gibi) bir boyutunun da bulunduğu göz önünde bulundurulmalıdır. Barışçıl bir doğaya sahip olduğu düşünülen mizah ve onun fiziksel çıktısı olarak gülme eylemi, negatif boyutu da hesaba katıldığında Mark Twain'in deyimiyle insanoğlunun elindeki şaşaalı bir silaha dönüşmeye muktedirdir. Bu yönüyle mizahın gücünün farkına varılması onun sadece bir hoşça vakit geçirme aracı olmanın ötesinde bir protesto aracı haline gelmesine ve gerektiğinde siyaset gibi bir güç savaşı arenasında rakiplerin saf dışı bırakılmasına yarayan bir üstünlük kurma silahına evirilmektedir.

Siyaset kadar büyük bir ciddiyetle icra edilmesi gereken bir mesleğin içinde mizahın ne işi olduğunu sorabiliriz. ${ }^{2}$ Ancak sorunun cevabı siyaset olgusunun tamamen bir güçler dengesine ya da savaşına dayanmasında gizlidir. Mizah, ehil ellerde olduğunda, üstünlük kurma savaşında tam bir silaha dönüşebilmektedir. Mizah, gerek yönetenler gerekse yönetilenler tarafindan kullanılabilir. Mizahın kullanımı sayesinde yönetenler güç savaşında kendilerini galibiyete ulaştıracak, yönetilenler ise kendilerini yönetenleri sarsacak ve onlara verdikleri iktidarı yerinden oynatabilecek bir silaha sahip olurlar. Siyaset sahnesi de bu silahın etkili bir biçimde kullanıldığı örneklerle doludur.

Türk ve İngiliz toplumlarında mizahın bir silah olarak kullanımına dair örnekleri aktarmadan önce, bu toplumların hayatlarında 19.yüzyıl3 ve sonrasında otoritenin mizaha bakışında öne çıkan noktaları genel hatlarıla değerlendirmek yerinde olacaktır.

\footnotetext{
2 Her ne kadar siyaset gibi rakibe üstünlük kurma amacına dayansa da siyaset dışında mizahın kullanımına belki de en son ihtimal verilebilecek alanlardan biri de savaştır. Savaşta mizahın kullanımına dair bkz: (Kılınç, 2007).

3 Türk Siyasal hayatında Mizahın 20. Ve 21. Yüzyıldaki durumu hakkında yapılmış bir çalışma için bkz: (Türk, 2015).
} 


\section{Türk ve İngiliz toplumlarının hayatında mizah-siyaset ilişkisi}

19.yüzyılın ağır basan ciddiyetine rağmen Viktorya döneminde İngiliz mizah yazarlı̆̆ının bazı büyük isimleri ortaya çıkmıştır. David Copperfield'daki Mr. Micawber karakterini yaratan Charles Dickens, Alice Harikalar Diyarında adlı eserin yazarı Lewis Carroll ve Viktorya döneminin en nükteli oyun yazarlarından biri olan Oscar Wilde 4 ve George Bernard Shaw 5 bu dönemin önde gelen yazarlarıdır (Ziv, 1988, s. 91).

İleride bir salgına dönüşecek karikatürcülük ise ilk temsilcisi olan Hogarth’1 18.yüzyılda sahneye çıkaracaktır. Sosyal taşlama örnekleri veren Hogarth'ın en popüler konusu başıboş ve ahlaksız hayatın yarattığı tehlikelerdir. 18.yüzyıldan 19.yüzyıla geçerken, sosyal sınıflar ayrımının iyice netleşmesiyle birlikte sosyal yaşam gittikçe politikleşmeye başlamış, böylece de karikatürler daha politik bir havaya bürünmüştür. Bu durum 19.yüzyılda İngiltere'nin mizah üzerine yoğunlaşan ilk yayını olan Punch’n (1841) ortaya çıkışını hazırlamıştır (Ziv, 1988, s. 92-93).

Bunun yanında İngiltere'de mizahın icra edildiği bir kurum olarak 'müzikhol'ler öne çıkmaktadır. Bu müzikholler eskinin popüler mizahi performanslarını pazarlamaya uygun bir hale getirerek sunmuşlardır. Sahnede icra edilen komik şarkılar müzikhollerin genel bir özelliği haline gelmiştir. Üst sınıfa hitap eden bu kurumlar, atası sayılabilecek şarkılı-yemekli kulüplerin yerini almıştır. Müzikholler, her ne kadar alkol ve fuhuşla anılan kötü şöhretli yerler haline gelse de hükümet tarafindan tolerans gösterilmiştir, özellikle de otoriteyi derinden sarsacak bir işçi hareketi korkusu bu noktada etkili olmuştur. Müzikholler daha önce de belirttiğimiz gibi pek çok noktadan kötü bir şöhrete sahip olsa da hükümet tarafından, iktidarı tehlikeye atabilecek bir işçi hareketini yatıştırabileceği için tolere edilmiştir (Ziv, 1988, s. 93-94). Bu durum mizahın siyasal anlamdaki gerginliğin yumuşamasını sağlayabilmesini göstermesi ve devlet eliyle mizahın farklı bir boyutta kullanımını göstermesi açısından önemlidir.

Popülerliğini koruyan müzikhollerde komik şarkıların yanında skeçler de sahnelenmekteydi ve bunların konuları genellikle üst sınıfın hafif bir taşlaması ve işçi sınıfının sıkıntılarıydı. Burada icra edilen mizah anlayışının en ünlü temsilcileri ise kariyerlerine bu müzikhollerde başlayan Stan Laurel ve Charlie Chaplin'dir. 2. Dünya savaşının sonrasında bile "varyete" adı altında varlı̆̆ını sürdüren müzikholler televizyonun ağırlı̆̆ını iyice hissettirmesiyle zamana yenik düşmüştür. Zaten radyo yayınlarıyla bile sarsılmaktayken, televizyon ona son darbeyi indirmiştir (Ziv, 1988, s. 93-95).

2. Dünya Savaşı sırasında radyo eğlence anlayışı ortaya çıkmıştır. Radyoda 'ITMA' (It's That Man Again: Yine O Adam) adını taşıyan ilk komedi programı, Avrupa'ya savaşı getirmekte olan Hitler Almanya'sının bir ajanı olan Funf tarafından tehdit edilen küçük bir kasaba ve belediye başkanının maceralarını anlatmaktadır. Savaş sonrasında da popülerliğini sürdüren radyo programları arasında Peter Sellers, Spike Milligan ve Harry Secombe'un yıldızlaştıkları 'The Goon Show' öne çıkmaktadır. Radyo programlarının yarattığı komedi anlayışı bugünkü sitcomların temellerini atmıştır (Ziv, 1988, s. 96).

Savaş sonrası dönemin politik taşlamalarıyla öne çıkan yazarı ise Hayvan Çiftliği adlı romanıyla tanınan George Orwell'dir. Bunun yanında politik mizah tiyatro sahnelerinde sergilenerek de varlığını sürdürmüştür. Punch gibi mizah üzerine eğilen yayınların yanında The Guardian ve Daily Mirror gibi

Oscar Wilde’ın nüktedanlığını gösterebilecek güzel bir örnek olarak şu cümleyi aktarmak yerinde olacaktır: "İngiliz taşra centilmenleri bir tilkinin ardından dört nala gidiyor - ă̆za alınamayanlar yenilemeyenlerin peşinde” (Ziv, 1988, s. 91).

Bernard Shaw'ın politik bakış açısını yansıtması açısından Man and Superman adlı oyunundan bir diyalog:

Mendoza: Ben bir haydutum, zenginleri soyarak yaşarım.

Tanner: Ben bir centilmenim. Fakirleri soyarak yaşarım. El sıkışalım (Ziv, 1988, s. 91). 
çok satılan gazetelerde yer alan gündemle ilgili karikatürlerle de politik mizahın örnekleri verilmiştir. Radyoların büyük oranda müzik yayınına ağırlı vermesiyle işlevini 6o'lardan itibaren kaybeden mizah programları, kendisine televizyonda Monty Python ekibi ve Benny Hill Show'la yeni bir boyut kazandırmıştır (Ziv, 1988, s. 95-102). 6o'lı yllarda politik mizah televizyon ve radyoda yerini sağlamlaştırırken, hiciv konusunda meşhur Private Eye dergisi de yayın hayatına başlayacaktır (Christopher, 2015, s. xx).

The Goon Show'la birlikte yldızlaşan Peter Sellers bunu Pembe Panter serisinde başroldeki rolüyle devam ettirecektir. Radyo şovlarının katkısıyla gelişim gösteren durum komedisi anlayışı televizyonlarda sitkom dizilerle varlığını sürdürmüştür. Dünya çapında tanınan politik mizah örneklerinden birisi olan Yes, Minister adlı sitcom dizi 1980 yllında BBC kanalında yayına başlamış ve 1990 yılına gelindiğinde ise politik hiciv içerikli bir yarışma programı olan Have I Got News for You ekranlardaki yerini almıştır (Christopher, 2015, s. xxii - xxiv).

İngiliz kültüründe söz konusu erken dönemlerde mizahın icra edildiği kurumlardan biri olan müzikhollerin yanında, ilerleyen teknolojiye bağlı olarak radyo programları, televizyon şovları ve tiyatro oyunlarıyla da mizahın kullanımı her alana taşınmış olmaktadır. Ancak ileride göreceğimiz gibi Türk mizahında gerek teknolojik gelişmelerin biraz daha geç takip edilebilmiş olması, gerekse sansür mekanizmasının bu kadar geniş kitlelere hitap edebilecek siyasal mizah unsurlarına izin vermemesi nedeniyle yakın bir döneme kadar elektronik kültür ortamında varlık gösteremediğini söyleyebiliriz. Aşağıda vereceğimiz örneklerden de anlaşılacağı üzere Türkiye'de mizahın siyasal boyutları modernleşme süreci boyunca ancak yazılı kültür ortamında oldukça uzun ve zengin bir gelişim dönemi geçirmiştir.

Osmanlı toplumunda mizahın biraz acımasız bir şekilde kullanıldığı örnekler genellikle hicivler olmuştur. Yazdığı hicivlerle adını duyuran Nefi'nin devlet kademesindeki kişiler hakkındaki hicivleri mizahın siyasette kullanımına bir örnektir. Ancak Nefi yazdığı bu hicivler yüzünden ölümle cezalandırılmıştır.

Saray çevresindeki bu görünümle birlikte, halk arasında da aşıkların taşlamaları, karagöz ve ortaoyunu gelenekleriyle siyasal mizahın yaşatıldığını söyleyebiliriz. Karagöz ve Hacivat'ın kimlikleriyle somutlaşan cahil halk ve ne dediği anlaşılmayan aydın kesim arasındaki çatışmalar bir bakıma toplumsal bir eleştiriyi de içersinde barındırmaktadır. Bu çatışmanın yanında Osmanlı gibi kozmopolit bir imparatorluğun sinırları içerisinde yaşayan insanlar da hayal perdesine Zenne, Arap, Frenk, Arnavut vb. karakterlerle yansımıştır. Ortaoyunu ise Karagöz ve Hacivat'ın sadece ete kemiğe bürünmüş halleridir. 19. yüzyılın ikinci yarısında ilan edilecek olan I. Meşrutiyet ile Osmanlı toplumu yazılı mizaha geçecektir. Yazılı mizaha geçişin ilk örneği Teodor Kasap tarafından 1870 yılında çıkarılan "Diyojen" dergisidir (Öngören, 1998, s. 60). Ancak 1873'te bu dergi kapatıldığında sahneye 1876'da "Çaylak" dergisi çıkacaktır. Bu iki dergi Osmanlı mizah basınına yön veren çok önemli iki dergi olarak öne çlkmaktadır.

Matbaanın Osmanlı topraklarına oldukça geç bir dönemde geldiği düşünülecek olursa Avrupai tarzda mizah yayınlarının çıkıyor olması oldukça önemlidir. Çünkü mizah gibi geniş kitlelere ulaşmaya yarayacak bir araç matbaanın kullanımıyla devreye girmiştir. Bu meselenin farkına varan ve geniş

Söz konusu dizi ülkemizde Sayın Bakanım adıyla uyarlanmıștır. 
kitlelere hitap etme konusunda mizahın önemini kavrayan Jön Türkler Diyojen dergisinin sayfalarından daha fazla insana ulaşmayı denemişlerdir (Özdiş, 2010, s. 112).

Mizahın etkililiğinin farkına varan Sultan II. Abdülhamit, bu durumun önünü alabilmek adına meclise mizah gazetelerini kaldırmaya yönelik bir tasarı getirmiştir. Meclis bu kanunu çıkarmasa da daha sonra 93 Harbinin başlamasıyla oluşan olağanüstü halde Meclis-i Mebusan'ı kapatarak kendi hakimiyet dönemini başlatan II. Abdülhamit, 32 yıl sürecek bu dönemde mizah basınının faaliyetini kısıtlayacaktır (Yücebaş, 1976, s. 4). Ancak bu durum sadece mizah dergilerinin yurt dişında basılıp ülkeye sokulmalarına neden olmaktan başka bir işe yaramamıştır: Londra'da Hayal, Hamidiye, Dolap; Kahire'de Pinti, Curcuna; İsviçre'de Beberuhi, Tokmak, ve yeri belirsiz Davul (Öngören, 1998, s. 61).

İkinci meşrutiyetin ilanının ardından eleştiri oklarını Sultan II. Abdülhamit yerine işlemeyen meşrutiyet ve İttihat ve Terakki partisine çeviren mizah dergileri bunun bedelini çok ciddi bir sansüre tabi tutularak ödeyecektir. İttihat ve Terakki, iktidara gelinceye kadar mizahın yardımını aldığı halde iktidara geldikten sonra mizah dergilerine göz açtırmamıştır. Onlarla ifade edilen mizah dergisi sayısı 1912 ylında üçe düşecektir. Bu da İttihat ve Terakki'nin uyguladığı sansürün boyutunu ortaya koymaktadır (Öngören, 1998, s. 63).

Birinci dünya savaşının ardından gelen Kurtuluş savaşı sırasında da mizah, siyasetin bir numaralı silahı olmuştur. İşgal kuvvetleri ve onlarla işbirliği halindeki İstanbul hükümetiyle mücadele eden Ankara hükümetinin sesi, Sedat Simavi’in çıkardığı Güleryüz dergisi olacaktır. Buna karşılık tavrını açıkça işgal kuvvetleri ve İstanbul hükümetinden yana koyan dergi ise Refik Halit Karay'ın çıkardığı Aydede dergisi olacaktır (Öngören, 1998, s. 68).

Kurtuluş Savaşı'nın ardından kurulan Türkiye'nin mizah yayınları meşrutiyet döneminin hiciv anlayışını benimseyecektir. Cumhuriyetin ilk yıllarında Aydede dergisinden geriye kalan kadronun kurduğu Akbaba ve Karagöz dergileri öne çıkacaktır (Öngören, 1998, s. 76). Bunun yanında Vasfi Mahir Kocatürk'ün peşpeşe çıkardığı Karagöz'le ilgili 6 kitap ve Muharrem Zeki Korgunal'ın Nasrettin Hoca ve Fıkralar kitabı da bu dönemde verilen mizah içerikleri eserler olarak zikredilmelidir.

İkinci Dünya savaşı yıllarına geldiğimizde ise Türk mizahında önemli bir yere sahip olan Aziz Nesin ve Rıfat Ilgaz’n yanında Sabahattin Ali ve Mim Uykusuz'un birlikte çıkardıkları Markopaşa dergisi gelecektir. Aziz Nesin bu derginin çıkış nedenlerini anlatırken bir yüceliş dönemi olarak nitelendirdiği Cumhuriyetin ilk yıllarının ardından gelen baskı ve bunalımın halk mizahını şahlandırdığını ve derginin çıkışını da bunun hazırladığını belirtir (Nesin, 2001, 47). Yine bu dönemin bir başka önemli figürü ise Cemal Nadir'dir. Öyle ki onun ölümünün ardından gazetelerin birinci sayfasına karikatür çizmeye hiç kimse cesaret edememiştir (Öngören, 1998, s. 89).

1960'lı yıllara gelindiğinde Aziz Nesin ve Rıfat Ilgaz gibi mizah yazarları öne çıkacaktır. Rıfat Ilgaz’ın Hababam Sınıfı adlı eseri önce dolmuş dergisinde parçalar halinde yayınlanacak ardından da kitap olarak çıkacaktır. Bu isimlerin yanı sıra daha sonra çok önemli yazar-çizer kadrolarını yetiştirecek olan Tef ve Dolmuş dergileri gelir.

1960'ların sonuna doğru ise Deve Kuşu Kabare tiyatrosu Haldun Taner, Zeki Alasya ve Metin Akpınar'ın öncülüğünde kurulacaktır. Güncel siyasal konuları ve toplumsal sorunları hicvetmesi nedeniyle iktidar tarafından hiçbir yerde hoş karşılanmayan kabare tiyatrosunun kurulması önemlidir. Türkiye gibi çalkantılı süreçlerden geçen ve kurumlaşma sancıları çeken genç bir ülkenin sık karşılaştığı sorunların 
mizah yoluyla irdelenmesi ancak çok sık kendisini güncelleyebilen bir tiyatro tarziyla mümkün olabilirdi. Zaten Türk siyasal mizahının hiciv ve taşlama temelli olduğu da düşünülecek olursa, tatll-sert bir dille söylemek istediklerini dile getiren kabare tiyatrosunun Türk mizah anlayışına ne kadar uygun olduğunu söylemek yanlış olmayacaktır.

1970'li yıllara geldiğimizde ise artık televizyonun da yavaş yavaş yaygınlaşmasıyla birlikte Türk toplumu da yabancı mizah örneklerini tanımaya başlamıştır. Bu arada televizyonun uyandırdığı büyük ilgi siyasilerin de dikkatini çekmiş ve televizyon ekranlarını ele geçirmek adına siyasiler arasında büyük mücadeleler başlamıştır (Öngören, 1998, s. 105). Ancak bu dönemin mizah adına öne çıkan en önemli figürü Oğuz Aral yönetimindeki Grrgır7 dergisi olacaktır. 500 bin satarak büyük bir başarıya imza atacak olan Gırgır, daha sonra kurulacak olan mizah dergilerinin pek çoğunun kadrolarını yetiştirecek bir okul olacaktır.

8o'li yılların sonuna doğru Olacak O Kadar televizyon ekranlarında boy göstermeye başlayacaktır. Özel kanalların da çoğalmasıyla birlikte Olacak O Kadar pek çok farklı kanalda izleyiciyle bulaşacak ve gündemi meşgul eden soysal ve siyasal sorunlara değinecektir. 90'lı yllarda televizyonlarda boy gösteren Plastip Show ve ana haber bülteni sonlarında çıan Salih Memecan'ın çizdiği Bizim City adlı kısa çizgi filmler bu dönemin siyasal mizah anlayışının örnekleridir. 200o'li yıllarla birlikte siyasal olaylara mizah yoluyla değinme misyonunu büyük oranda haftalık mizah dergileri gerçekleştirecektir. Televizyonlarda ise artık suya sabuna dokunmayan "eğlenme" odaklı bir mizah anlayışı hakim olacaktır.

Buraya kadar aktardığımız tarihi süreçler göz önüne alındığında, İngiltere'de hükümetin eliyle müzikhollerin oluşabilecek bir siyasi hareketi önlemek amacıyla kullanılması, Osmanlı döneminde mizah dergilerinin kamuoyu oluşturmak amacıyla bir araç olarak görülmesi, mizahın bu etkinliğinin farkına varan yöneticilerin sansür mekanizmasını devreye sokması ancak mizahın etkin bir silah oluşunun göstergesidir. Mizahın, savunma/saldırı, statü zedeleme, değersizleştirme gibi işlevleri, genel anlamda siyasi mekanizmaların tolerans gösterebileceği durumlar değildir. Mizahın, otoriter yapılanmayı sevmediği gibi iktidar cenahı da mizaha karşı mesafelidir (Kamiloğlu, 2014, s. 35).

Mizahın siyasal alanda kullanılmasının en önemli nedenleri ya otoriteyi eleştirebilmeye imkan bulmak yada rakipler üzerinde üstünlük sağlamaktır. Bu nedenle günümüze kadar gelen mizah kuramları arasından üstünlük kuramının ${ }^{8}$ konumuzu aydınlatması açısından daha yararlı olacağını söyleyebiliriz. Bu nedenle kısaca üstünlük kuramına değinmemiz gerekecektir.

\section{2. Üstünlük kuramı ve siyasal alanda mizahın kullanımına dair örnekler}

Mizah üzerine yapılan tartışmaların kaçınılmaz teması insanların “üstünlüklerini” gösterme ihtiyacıdır. Bundan dolayı da tartışmalar gülmenin sürekli olarak bir silah olarak kullanılması üzerinde yoğunlaşır (Bergler, 1956, s. 272). Kuramın temellerini atan Aristoteles ve Platon gülmenin aslında alayın bir türü olduğu konusunda birleşmişlerdir ve dolayısıyla alayın bir silah olduğunu söylemenin yolunu dolaylı da olsa açmışlardır. Bununla birlikte insanlar kendilerine gülünmesinden hoşlanmayacakları için gülme, insanları hizaya sokacak bir düzenleyici olarak da düşünülebilir (Morreall, 1997, s. 9). Dolayısıyla alay konusu olmamak adına eksiklik ve zayıflık göstermemesi gereken insan da buna göre hareket edecektir.

Gırgır Dergisi hakkında ayrıntılı bilgi için bkz: (Çetinkaya, 2006).

Üstünlük Kuramı ve diğer Mizah Kuramları hakkında ayrıntılı bilgi için bkz: (Eker, 2009 ve Emeksiz, 2010).

Adres

Kurklareli Üniversitesi, Fen Edebiyat Fakültesi, Türk Dili ve Edebiyatı Bölümü, Kayalı Kampüsü-Kırklareli/TÜRKIYE e-posta: editor@rumelide.com
Adress

Kirklareli University, Faculty of Arts and Sciences, Department of Turkish Language and Literature, Kayalı Campus-Kırklareli/TURKEY e-mail: editor@rumelide.com 
Eksiklik veya küçük düşme kaygısı taşıyan insan, toplum tarafından başarısız, yeteneksiz, niteliksiz olarak adlandırılma ya da tanınma endişesi içindedir. Herhangi bir olayda, etken kişinin, sahip olması gereken nitelikleri koruyamayarak bu olumsuz özelliklerle ortaya çıkması, edilgen kişide, aynı olumsuz özellikleri bünyesinde barındırmayıp toplum tarafından küçük düşürülmemenin verdiği üstünlük duygusunu ortaya çlkarır (Eker, 2009, s. 140). Bu üstünlük duygusunun tadına varan kişi de sonuç olarak anlık bir zaferle gülecektir.

Teori, İngiliz filozof Thomas Hobbes'un (1588-1679) katkılarıla birkaç yüzyll daha geçerliliğini korumaya devam etmiştir. Hobbes da gülmenin başkasının zayıflğına karşılık kendimizde olduğunu fark ettiğimiz üstünlükle kazanılan anlık bir zaferden kaynaklandığını belirtir (Martin, 2007, s. 44). Bu noktada da karşıdakinin bize göre daha aşă̆ıda bir konumda bulunmasından kaynaklanan bir zevkle gülme eyleminin gerçekleştiğini ve daha önce de belirtildiği gibi gülmenin içerisinde üstünlük kurmaya yönelik bir saldırganlık barındırdığını belirtmeliyiz.

Charles Gruner da gülmenin malzemesi olan mizahı "neşeli saldırganlık” olarak niteler. Ancak bu gerçek anlamda insanlara fiziksel saldırmayı ve onları yaralamayı içeren bir saldırganlık değildir; daha çok, çocukların ya da yavru hayvanların kavgalarına benzer. Bundan dolayı, Gruner mizahın bir çeşit oyun olduğunu vurgular. Özellikle, Gruner’in aklındaki kazananların ve kaybedenlerin olduğu, bir yarışma ya da müsabakadır. Gruner'a göre, mizahtan alınan zevk uzun bir mücadelenin ardından kazanılan bir zaferin hemen ardından gelen şaha kalkmış duyguların verdiği mutluluğa yakındır (Martin, 2007, s. 45). Yine benzer bir şekilde, insanın ilkel zamanlardan kalma bir davranışı olarak nitelendiren Albert Rapp da gülmeyi "bir eski zaman ormanında geçen düellonun zafer kükremesi" olarak nitelemektedir (Morreall, 1997, s. 13). Burada dikkat edilmesi gereken nokta karşı karşıya gelen unsurlardan etken olanın edilgen olanı zor bir duruma düşürmesinin ortaya çıkardığı durumun gülme eylemine sebep olmasıdır. Şöyle ki hem rakibini alt edenin hem de toplum önünde küçük düşenin yerinde olmamanın verdiği bir üstünlük duygusu ile mizahın en önemli fiziksel çıktısı olan gülme eylemi ortaya çıkacaktır.

Üstünlük kuramının buraya kadar aktardığımız yönleri şüphesiz siyasetin doğasıyla örtüşmektedir. Tamamen hassas dengeler üzerine kurulu bir üstünlük savaşının kazanılması için rakiplerin zayıflıklarının üstüne gitmek ve tatlı-sert bir saldırganlık sergilemek gerekecektir. Bu saldırganlık rakipler üzerinde fiziksel bir yaralamayı gerektirecek vahşilikte olmayacaktır. Bunun yerine oldukça seviyeli bir şekilde karşıdakinin moral olarak çökertilmesini sağlayarak gülme eylemi açığa çıkacak ve dolayısıyla küçük düşürülmeye yol açacak, böylelikle daha büyük bir zafer ve üstünlük kazanılacaktır. Siyaset gibi medeni toplumları yakından ilgilendiren bir alanda mizahın kullanımını, içerisindeki saldırganlık unsurunu da göz önünde bulundurarak tam olarak kavrayabilmek açısından Feinberg’in açıklamalarını dikkate almak gerekir:

\begin{abstract}
"Kendilerini medeni olarak nitelendiren toplumlarda, sözlü mizahtaki saldarı, genellikle dolaylddrr. Öyle ki, esprinin tadına varan kişiler, bir kişi veya bir fikre olan çirkin veya rahatsız edici bir saldırıya maruz kalmadikları gibi, kendilerini sadist veya kaba görmek zorunda da kalmazlar. Saldırıyı gizlemede çapraşıklğın derecesi, kabaca, bir kültürün başardığını iddia ettiği medeniyet seviyesiyle orantılı olarak artar görünür. Saldırganhı̆gn gizlenmesi gerçekte iyilik yüzünden değil, uyum sağlamadan dolayıdır. Medeni toplum, hakl çıkartılmamış saldırganlı̆̆ ifade etmenin uygun olmadığım savunur gibi görünür. Dolaylı saldırı, saldırganlı̆̆ kaldırmak için değil, onu gizlemek için sarf edilen ikiyüzlü bir çabadır" (Feinberg, 2004, s. 108).
\end{abstract}

Tarihi süreç içerisinde yönetilenlerin eleştiri oklarını yönetenlere yöneltebilmesini sağlayan mizah, pek çok siyasinin de muhataplarını ya da rakiplerini alt etmesinde bir silah olarak kullanılmıştır. Dolayısıyla, 
mizahın bu etkin rolünü gösterebilmek adına hem İngiliz hem de Türk siyasetinde verilen bazı örnekleri aktarmak yerinde olacaktır.

George Mikes’a göre İngilizler dünyada mizah duygularıyla aşırı derecede övünen tek millettir. Parlamentoda, çok ciddi akademik tartışmalarda, hatta cenaze törenlerinde, Shakespeare'den, Lewis Caroll'a oranla daha az alıntı yapılmaktadır. İngilizler arasında barınabilmek için İngiliz mizah anlayışı denilen bu fenomene dayanmak ve alışmak gerekmektedir. Bir İngiliz tarafından uğrayabileceğiniz en büyük hakaret mizah duygusundan yoksun olduğunuzun söylenmesidir (Mikes, 1980, s. 10-11). Bütün bu noktaları hatırda tutarak İngiliz siyasetinden alınan mizahi örneklere geçmek mümkündür.

İngiliz parlamentosunda boy gösteren önemli hatiplerden biri olan Richard Brinsley Sheridan, St. James caddesinden geçerken kraliyet ailesine mensup iki dükle karşlaşır. Düklerden biri der ki:

\begin{abstract}
"Bay Sherry, seni gördüğüme sevindim. Biz de biraz önce senden söz ediyorduk. Yalnı bir nokta üzerinde anlaşamadık: Sen büyük bir aptal mısın, yoksa büyük bir sahtekar mı?”

Sheridan hiç bozuntuya mahal vermeden iki dükün arasina girip kollarıyla biraz mesafeyi ayarladıktan sonra, "Bunu bilmeyecek ne var, ben şu anda ikisine de aynı uzaklıktayım!" diyerek aradan suyrliverir (Yakar, 2008, s. 9).
\end{abstract}

Örnekte görüldüğü gibi mizah yoluyla yapılan bir saldırı yine aynı şekilde mizahla savuşturulmuş ve rakibe ağır bir darbe indirilmiştir. Mizahı her iki taraf da üstünlük kurmak amacıyla ve örtülü bir saldırganlıkla kullanmıştır. Burada değinilmesi gereken konu ilk başta saldırıyı gerçekleştirenin, Ross'un (1998, s. 58) deyimiyle "kendini küçültücü” mizah örneği vermiş olmasıdır. Buna göre kurban ya da nesne olarak görünen kişi kendisine verilen malzemeyle rakibini geri dönüp alt etmiştir.

19.yüzyılın başlarında yetişmiş hatiplerden Benjamin Disraeli de muhataplarını nükteli sözlerle köşeye sıkıştıran bir başka siyaset adamıdır. Bir seferinde Disraeli kürsüde konuşurken muhaliflerden biri oturduğu yerden şöyle seslenir:

"Bay Disraeli, sesini yükselt sesini! Bize ulaşmıyor."

Disraeli sözlerine ara vererek, şöyle yantlar:

“Gerçekler yavaş gider, ama üzülme zamanla sana da ulaşacaktı” (Yakar, 2008, s. 17).

Mizahın üstü kapalı saldırganlığı kendisini burada da hissettirmektedir. Disraeli, hoşgörü çerçevesi içerisinde muhatabına, söylediği doğru sözlerin kendisinin işine gelmediğini ve dolayısıyla doğru sözün kendisi gibi yalancıların işine pek yaramadığı için çok daha geç yayılacağını belirtmektedir.

İngiliz siyasetinde mizahı etkin bir silah olarak kullanan isimlerin başında kesinlikle Winston Churchill gelmektedir. Churchill bir konuşma sırasında kendisine "hain" diyen bir muhalifi için şu sözleri kullanır:

“Şuna bilhassa dikkat ediyorum: Siyasi münakaşalar hararetlendiği zaman hirçın tabiatlı ve sınurh zekası olanlar kabalaşmayı seçiyorlar” (Yakar, 2008, s. 28).

Chruchill’in söyledikleri mizaha siyasette neden ihtiyaç duyulduğu sorusuna bir cevaptır. İngiliz siyasetçilerin mizahı kullanma nedeni hem saldırganlıkla üstünlük kurma hem de saldırganlıklarını da gizleyerek kaba görünmemektir. Saldırılarını kamufle ederek zekalarını ortaya koymakta, bu sayede seviyelerini ve çok önem verdikleri "centilmen" kimliklerini korumaktadırlar. Aşağıda vereceğimiz örnek mizahla süslenmiş İngiliz tipi saldırgan bir mizahın örneğidir. 
Bir konuşma sırasında Churchill muhalif milletvekili Morrison’a önce iltifatta bulunur:

"Mr. Morrison usta bir sanatçıdır."

Morrison ayağa kalkarak:

"Muhterem centilmen beni yüceltti. Kendisine teşekkür ederim" der.

Churchill, beklediği anın geldiğini görünce onu ayaküstünde yakalayarak can ahcı vuruşunu indirir:

"Sayın baylar bayanlar! Ancak ne var ki Mr. Morrison sanatını, sahtekarlk alanında kullanmaktadır" (Yakar, 2008, s. 31).

İngiliz siyasetinde yönetenlerin birbirlerine karşı kullandıkları kadar yönetilenler de mizahı aynı sertlikte yönetenlere karşı kullanabilmektedir.

Dünyanın pek çok yerinde olduğu gibi İngiliz mizahı içinde de politik taşlamanın hedefleri arasında hükümetin, politikacıların, asker sınıfının, toplumda yüksek zümrelerinin hedef tahtasında yer alması söz konusudur (Blake, 2007, s. 16). 1984'te IRA'nın gerçekleştirdiği bir bombalı saldırıda İngilizlerin Demir Leydisi Margaret Thatcher'ın en ateşli savunucularından biri olan ve işsizlere "On your bike!" ("bisikletinizin üzerine" yani bisikletinize binip dolaşarak bir iş arayın) diyerek insanların tepkisini çeken Norman Tebbit de ciddi biçimde yaralanır. Bir istasyonun üzerine bu olay üzerine birileri tarafindan şu yazılır:

“On your cructhes, Tebbit!” (“Koltuk değneklerinin üzerine Tebbit!”) (Ziv, 1988, s. 101)

Bir bakıma oldukça acımasızca nitelendirilebilecek bu olay İngiliz mizah anlayışında oldukça olağandır. Mikes İngiliz mizah anlayışının üzerine dayandığı üç noktayı 1.Kendine gülmek, 2.Olduğundan küçük göstermek ve 3.acımasızlık olarak nitelemektedir (1980, s. 44-55). Dolayısıyla bizim için oldukça kötü görünebilecek bu durum İngilizler için mizahın olağan rutini içerisinde değerlendirilebilir.

Mizahın siyasilere karşı kullanımına aşağıda vereceğimiz bir başka örnek yine tahammül sınırlarını zorlayabilecek türdendir:

Muhafazakar partinin propagandacılarından biri, bir çiftçiye giderek ondan oy ister.

'Ben sosyalistlere oy veririm' der yaşl adam, 'tıpkı daha önce babamın ve onun babasının yaptığı gibi'.

Propagandacı alaycı bir şekilde 'Madem öyle' der 'eğer baban ve onun babası da bir ahmak olsaydı ne yapardin?'

'O zaman, muhafazakârlara oy verirdim' (Mikes, 1980, s. 55).

Bu durum tam olarak İngilizlerin "mizah duygusuna sahip olmak" diye nitelendirdikleri meseleye bir örnektir. Mizahi yolla bir hicvetme söz konusudur. Çiftçi burada tüm muhafazakârlara dolaylı yoldan ahmak demiştir ancak bu durum İngilizler açısından hoş karşılanmalıdır çünkü içinde mizah vardır. İngilizlere göre mizahsız bir hiciv küfürdür (Özcan, 2002, s. 13). Ayrıca bu durumda çiftçiye verilecek saldırgan ve öfkeli bir tepki de "mizah duygusundan yoksun olmak" anlamına gelecektir ki bu durum kişiyi toplum nazarında daha da küçük düşürecektir.

Yukarıda aktardığımız örnekler bize Anglo-sakson mizah anlayışının doğasını göstermektedir. Gershon Legman'ın düşüncesi bu durumu daha iyi açıllamaktadır: 
"Mizah maskesi altında, toplumumuz herkes tarafindan herkese karşı sonsuz saldırlara izin verir" (Feinberg, 2004, s. 111).

Benzer şekilde Lord Byron da "In Praise of the Turk" adlı şiirinin bazı dizelerinde Türk toplumu açısından oldukça taraflı bir bakış açısı sergilese de İngilizler için mizah ve nüktenin değişilmezliğini ve bunun kimlikleri için ne kadar önemli olduğunu ortaya koyar:

“...

Onlar okuyamazlar ve bu yüzden eleştirmede tutuk değildirler;

Ne de yazabilirler, bu yüzden ilham perisini etkileyemezler;

Ne nükteli sözleri ne de zeka kıvraklı̆ı görülmüsstür

...”(Bishop, 1942, s. 115).

Byron'ın bu sözleri içerisinden cımbızla çekilip alınacak noktalar İngilizler için nükte ve zeka kıvraklığının sahip olunması gereken en önemli özellik olduğudur. Türkler onun nazarında bu özelliklere sahip değildir ve bu yüzden hicvedilmelidir.

Türk siyasetinde de mizahın kullanıldığı pek çok örnek vardır. Her ne kadar günümüzde siyasetin gün geçtikçe daha asık bir surat ve tahammülsüzlükle yapıldığı düşünülecek olsa da en azından tarihimizde bunun örneklerini görmek mümkündür. Kusurlu olan noktayı bulup çıkarmak ve hazırcevap olmak Türk toplumu için çok değer verilen iki özelliktir. Hiciv ve taşlama geleneğinin edebiyatımızda oldukça kuvvetli olduğu düşünülecek olursa durum daha da net anlaşlacaktır. Bir bakıma sözlü kültürün çok uzun bir hâkimiyet sürdüğü bir toplum için bu durum oldukça doğaldır. Aşağıda vereceğimiz örnek sözünü ettiğimiz duruma iyi bir örnek teşkil edecektir.

Son Osmanlı mebusları arasında geçen bir diyalog mizahın siyasal alandaki çatışmaları hafifletmesi ve zekayı açığa çıarması açısından oldukça önemlidir. İttihat ve Terakki Partisi mensuplarından olan Hüseyin Cahit Bey, Rıza Nur Bey'e:

"Sen beni boyuna eleştirip duruyorsun. Oysa sizin kurduğunuz parti de mütecanis değil. Sizde de mutaassıb var, muhafazakârı var; hatta Hristiyan olan bile var. Siz de kozmopolit bir yapıya sahipsiniz. Kendi içinizi görmüyorsunuz bir de kalkıp bize sataşıyorsunuz"

Bunun üzerine Rıza Nur'un cevabı şöyle olur:

"Sizin partinize hiç diyecek yok doğrusu! Partiniz, iki büyük görevi yerine getirdi. Bunlardan birincisi Balkan bozgunu. İkincisi de Sevr antlaşması...” (Yakar, 20o8, s. 54).

Cevabın yıkıcılı̆̆ı ve rakibe karşı sağladığı üstünlük tartışılamaz derecede bellidir. Tatlı-sert bir dille gerçekleştirilen saldırı rakibin bir daha ayağa kalkmasına müsaade etmeyecek cinstendir. Ayrıca daha önce değindiğimiz hazırcevaplığı da içermektedir ve Türk mizah anlayışının siyasal alana taşınmış bir örneği olarak değerlendirilmeye müsaittir.

Aktaracağımız bir diğer örnek de hazırcevaplık ve nüktedanlığın Türk mizah kimliğindeki baskınlığını gösterir cinstendir. Fransa Girit’i Osmanlılardan alıp Yunanistan'a vermek istemektedir. Fransız imparatoru III. Napolyon, yarı şaka yarı ciddi olarak, hasta Osmanlı Devletinin omuzlarından bu yükü almak istediğini söyler.

Fuat Paşa ona gülümseyerek karşıllk verir: 
“Haşmetmeab, siz bendenize Türkiye’den başka bir devlet gösterebilir misiniz ki, üç yüz senedir dışarıdan sizlerin, içeriden bizlerin devaml tahribine rağmen direnebilmiş olsun. Evet, üç yüz senedir, siz dışarıdan biz içerden bu devleti yıkamadık; hatta sarsamadık” (Yakar, 2008, s. 72).

Burada hazırcevaplık dışında üzerinde durulması gereken diğer nokta kendini bilmek ya da daha doğrusu kendini de eleştirebilmektir. Fuat Paşa bir taraftan muhatabına oldukça ince düşünülmüş bir cevap verirken eleştiri oklarını kendi üzerine de çevirebilmiştir. Kendini eleştirebilmenin baskınlığını göstermesi açısından Fransız mizah yazarı Pierre Daninos'un Türk toplumuna dışarıdan bakan biri olarak yaptığı yorum oldukça önemlidir:

“Türklerin mizahı, hiciv ve nükteleri, ve bu nüktelerdeki değişiklik atalarından kalan vatan aşkı gibi kuvvetlidir. Türkler yüksek seviyeli insanlardır. Özellikle ìyi eğitim görmüş Türkler kuvvetli bir kişiliğe sahiptir. Bu kişiliğin kuvvetini, ciddilikten neşeye, resmilikten samimiliğe, takdirden istihzaya, üzüntüden hicve çarçabuk geçebilmelerinde aramak gerekir.

Türkler her şeye gülmesini bilirler. Gülmeye de kendilerinden başlarlar. Müthiş anlayışlıdırlar. En küçük kavrayışsızlı karşısında "Türkün aklı sonradan gelir” sözüyle kendi kendileriyle alay ederler" (Yücebaş, 1976, s. 15).

Türklerin kendilerine gülebilmelerinin yanında hazırcevap olmalarının da mizahlarının esas unsurlarında olduğuna daha önce değinmiştik. Ankara'da verilen bir yemek sırasında Atatürk'ün bir Anzac ile arasında geçen hadise bu duruma uygun bir başka örneği barındırmaktadır. Haidse, Çanakkale Savaşları gibi hem Türk ulusunun bilincinde önemli bir yer tutan hem de Yeni Zelanda ve Avustralyalıların ulus kimliklerinin inşasının da önemli yapıtaşlarından birini oluşturan hassas bir zeminde gerçekleşmektedir:

Ankara'da Atatürk adına bir yemek verilir. Yemeğe yabancı konuklar da davetlidir. Herkes gayet güzel eğlenirken Atatürkün gözünün içine dik ve oldukça sert bir ifadeyle bakan bir İngiliz davetli takılyor. Atatürk, yaverine "Şu karşıdaki adama git bana niye öyle sert baktığın sor da gel" diyor.

Yaver gidiyor ve sebebini öğrenip geliyor ve diyor ki:

"Çanakkale savaşında adamın babasını öldürmüşsünüz de o yüzden sinirliymiş" diyor.

Atatürk bunun üzerine diyor ki:

“Sor bakalım, babasının ne işi varmış Çanakkale’de?” (Yakar, 2008, s. 88).

Burada öne çıkan nokta Atatürk'ün kendisine yöneltilen saldırıyı aynı düzeyde savuşturmasıdır. Karşıdakinin bu soruya cevap verecek hiçbir dayanağı kalmamıştır ve böylelikle mizah sayesinde böylesine bir çatışmadan bir üstünlük çıkmıştır.

Edebiyat geleneğimiz içerisinde hiciv ve taşlama geleneğinin kuvvetine daha önce de değinmiştik. Biri Osmanlının son dönemlerini, diğeri hem Osmanlı hem de Cumhuriyeti görmüş figürler olarak Şair Eşref ve Neyzen Tevfik hicivleriyle anılması gereken iki büyük şahsiyettir. Yönetilenlerin eleştiri oklarını yöneticilere çevirebilmesinin en önemli aracı olan hicvin önemli iki isimi olan Eşref ve Neyzen Tevfik oldukça sert bir üslup kullanmışlardır. Burada aktaracağımız ilk örnek Şair Eşrefe aittir. Eşref Makedonya da elden çıkınca Sultan II. Abdülhamit'e şu hicvi yazar:

"Padişahım! Bir drahte döndü ki vatan

Daima bir baltadan bir dah hali kalmiyor

Gam değil amma bu mülkün böyle elden çlkması

Gitgide zulüm etmeye elde ahali kalmiyor" (Yakar, 2008, s. 82). 
Eşrefin kullandığı iğneleyici dil vatan bildikleri toprağın elden çıkmasının yarattı̆̆ı üzüntüyü dile getirirken diğer yandan ülkedeki siyasal ortamdan bir şikayeti de barındırmaktadır. Tahammül sınırlarını oldukça zorlayabilecek bir görünüme sahip olan bu şiir hem kötü gidişe hem de baskıya karşı oldukça ince bir üslupla eleştiri yöneltebilmeyi sağlamaktadır. Burada mizahı doğuran nokta Eşref in kendisinden daha yüksek konumda bulunan bir kişiyi şartların elverdiği ölçüde gülünç duruma düşürmesidir. Zaten, bizden yukarıda bulunanları gülünç duruma düşürmekten belirgin bir haz duyarız. Çünkü bu bizim, güçleriyle bizi değersizleştirmeleri hissinden kurtulmamızı sağlar. Gücü elinde bulunduranlar bu sayede bir anlık da olsa kurban haline gelir (Mindess, 1971, s. 45).

Bir diğer siyasal mizah örneği ise cumhuriyet döneminde de eser veren ve sivri diliyle karşılaştı̆̆ olumsuzlukları eleştiren Neyzen Tevfik Kolaylı'ya aittir. Eleştiri oklarını toplumsal düzene de yönelten Neyzen Tevfik oldukça sert bir üslupla düşüncelerini dile getirir:

Kime sordumsa seni doğru cevap vermediler

Kimi alçak, kimi hırsız, kimi deyyus dediler

Künyeni almak için, partiye ettim telefon,

Bizdeki kayıtlara göre şimdi o mebus dediler (Usta, 1998, s. 322).

Yukarıda verilen örnekler göz önüne alınacak olursa Türk siyasal mizahında bir yanda liderlerin verdiği örnekler, diğer yanda halkın yönetenlere eleştirilerini oldukça sert bir şekilde yönelttiği hicivler ağır basmaktadır. Hiciv temelli bir gelişim gösteren eleştiri anlayışımızın kuvveti kendisini mizah dergilerinin günümüzdeki yaygınlığıyla sergilenmektedir. Bir bakıma mizah dergileri artık eskisi gibi kuvvetli örnekleri verilmeyen manzum hiciv anlayışının çizgiler ve konuşma balonlarıyla devam ettirilişidir diyebiliriz.

\section{Sonuç}

Buraya kadar verdiğimiz örnekler üzerinden hareketle hem İngiliz hem de Türk kültürü açısından siyaset alanında verilen mizah örneklerini değerlendirerek bir karşılaştırma yapmak mümkündür.

Her iki kültürün siyasal mizah anlayışında farklılıklar bulunduğu kadar ortaklıklar da göze çarpmaktadır. Üstünlük kuramının sunduğu çerçeve içinden bakacak olursak ele aldığımız örnekler eksikliği ortaya koymayı veya küu̧ük düşürme kaygısının, başarısız, yeteneksiz, niteliksiz olarak adlandırılma ya da tanınma endişesinin insanın hareketlerinde bir ölçü ve hizaya sokma etkisinin bulunduğu ve mizahın fiziksel çıktısı olan gülmenin tam olarak bu noktalar üzerinden gerçekleştiği görülmektedir. Mizahın kullanımı, siyaset gibi oldukça hassas bir zemin üzerinde gerek politika üreticilerinin muarızlarını sert ama oldukça korunaklı bir yolla alt etmelerini sağladığı gibi, yönetilenlerin de zaman zaman kendilerinden daha üst konumda bulunanları mizahın korunaklı ancak bir o kadar saldırmaya imkan veren kozası içerisinden eleştirebilmelerini ve sorgulayabilmelerini sağlamaktadır.

İngiliz kültürü açısından büyük önemi olan mizah duygusu siyasal düzlemde nükteli ve ince bir zeka göstergesi olmak kaydıyla her türlü saldırıyı yapma firsatı vermektedir. Benzer bir durumun Türk mizahı açısından da mümkün olduğunu söyleyebiliriz. Türk toplumu açısından kimi zaman siyasal mizahın tehlikeli bulunması nedeniyle pek çok mizah yayınının sansüre tabi tutulmasıyla akamete uğradığı durumlar da mevcuttur. 
İngiliz mizah anlayışındaki saldırganlık Türk mizah anlayışında da özellikle hiciv alanında görülebilmektedir, ancak yukarıda İngiliz mizahından aktardığımız kimi örneklerde görüldüğü üzere yapılan saldırılar Türk mizah kültürü açısından aşırı olarak nitelendirilebilecek düzeydedir.

İngiliz siyasal mizahında verilen bazı örnekler kimi noktada zalimliğe varabilmektedir. Ancak benzer bir anlayışın Türk mizah anlayışı için geçerli olduğunu söyleyemeyiz. Türk mizah anlayışı, tıpkı Nasrettin hoca fikralarında pek çok örneğini gördüğümüz saldırıya aynı dozda karşılık verme ve hazırcevaplığın ağır bastığı bir anlayıştır.

\section{Kaynakça}

Bergler, E. (1956). Laughter and the Sense of Humor. New York: Intercontinental Medical Book Corporaiton.

Bishop, M. (1942). A Treasury of British Humor. New York: Coward-McCann Inc.

Blake, J. B. (2007). Playing with Words: Humor in the English Language. Londra: Equinox.

Christopher, D. P. (2015), British Culture: An Introduction. New York: Routledge.

Çetinkaya, G. (2006). Grrgır Dergisinin Türk Halkbilimi Açısından İncelenmesi (Yayınlanmamış Yüksek Lisans Tezi). Ankara: Hacettepe Üniversitesi Sosyal Bilimler Enstitüsü.

Eker, G. Ö. (2009). İnsan, Kültür, Mizah. Ankara: Akçă̆ Yayınları.

Emeksiz, A. (2010). Bir İstanbul Kahraman Bekri Mustafa. İstanbul: Mühür Kitaplı̆̆ı.

Feinberg, L. (2004). The secret of humor (Çev. Feinberg, L. ve Koçsoy, F. G. Ö.). Milli Folklor, 62, 105113 .

Kamiloğlu, Z. (2014). 2002-2011 Dönemi Türk Siyasetinde Mizah (Yayınlanmamış Yüksek Lisans Tezi). Ankara: Hacettepe Üniversitesi Sosyal Bilimler Enstitüsü.

Kılınç, A. (2007). Üstünlük kuramı bağlamında harp ve mizah. Milli Folklor, 73, 55-60.

Martin, R. A. (2007). The Psychology of Humor. Burlington: Elsevier Academic Press.

Mikes, G. (1980). English Humour for Beginners. London: Andre Deustch.

Mindess, H. (1971). Laughter and Liberation. Los Angeles: Nash Publishing.

Morreal, J. (1997). Gülmeyi Ciddiye Almak. İstanbul: İris.

Nesin, A. (2001). Cumhuriyet Dönemi Türk Mizahı. İstanbul: Adam yayınları.

Öngören, F. (1998). Türk Mizahı ve Hicvi. İstanbul: İşbankası Yayınları.

Özcan, Ö. (2002). Türk Edebiyatında Hiciv ve Mizah. İstanbul: İnkılap Yayınları.

Özdiş, H. (2010). Osmanlı Mizah Basınında Batılılaşma ve Siyaset. İstanbul: Libra Yayınları.

Ross, A. (2005). Language of Humor. United Kingdom: Taylor \& Francis e-Library.

Türk, T. K. (2015). Türk Siyasal Hayatında Politik Mizah (Yayınlanmamış Yüksek Lisans Tezi). İstanbul: Marmara Üniversitesi Sosyal Bilimler Enstitüsü.

Usta, R. (1998). Neyzen Tevfik: Tercüme-i Halim. İstanbul: Broy Yayınları.

Yakar, F. (2008). Mizahi Siyaset. İstanbul: Başlık Yayın Grubu.

Yücebaş, H. (1976). Hiciv ve Mizah Edebiyatı Antolojisi. İstanbul: Milliyet Dağıtım.

Ziv, A. (1988). National Styles of Humor. London: Greenwood Press. 